\title{
Studi Identifikasi Biodiversitas Gastropoda di Kawasan Situ Gintung Kota Tangerang Selatan Provinsi Banten
}

\author{
Giry Marhento $^{1^{*}}$, Mashudi Alamsyah ${ }^{1}$ \\ ${ }^{1}$ Program Studi Pendidikan Biologi, Fakultas MIPA, Universitas Indraprasta PGRI \\ *email: girymarhento@gmail.com
}

\begin{tabular}{l} 
Article History \\
\hline Received: \\
02/04/2021 \\
Revised: \\
10/04/2021 \\
Accepted: \\
05/05/2021
\end{tabular}

Kata kunci:

Identifikasi

Keanekaragaman

Gastropoda

Situ Gintung

\begin{abstract}
ABSTRAK
Tujuan penelitian ini adalah untuk mengetahui dan menganalisis struktur komunitas Gastropoda, keanekaragaman gastropoda, kepadatan Gastropoda, dan penyebaran Gastropoda di kawasan Situ Gintung Kota Tangerang Selatan Provinsi Banten pada tahun 2020. Pengambilan pada sampel Gastropoda serta pengukuran parameter fisika dan kimia lingkungan sekitar dilakukan di delapan titik penelitian yang berada di kawasan Situ Gintung Kota Tangerang Selatan Provinsi Banten, yang terbagi atas empat stasiun, yang masing-masing memiliki dua sub stasiun. Sampel diambil dan dilakukan pengukuran faktor fisika dan kimia lingkungan. Sampel selanjutnya diidentifikasi tiap spesiesnya, serta diidentifikasi menggunakan Indeks Kemerataan, Indeks Keanekaragaman Shanon-Wiener, dan Indeks Dominasi Simpson. Hasil penelitian diperoleh sebanyak lima spesies dari Gastropoda, yaitu Pomacea caniculata, Bellamya javanica, Melanoides tuberculata, Thiara scabra, dan Indoplanorbis exustus. Keanekaragaman Gastropoda di kawasan Situ Gintung Kota Tangerang Selatan Provinsi Banten termasuk kategori sedang. Kemerataan Gastropoda di kawasan Situ Gintung Kota Tangerang Selatan Provinsi Banten termasuk kategori lebih merata. Tidak ada spesies yang mendominasi perairan di kawasan ini.
\end{abstract}

Key word: Identification Diversity Gastropods Situ Gintung

\section{ABSTRACT}

The purpose of this study was to determine and analyze the gastropod community structure, gastropod diversity, gastropod density, and distribution of gastropods in the area of the southern city of Tangerang, Banten Province in 2020. Sampling of gastropods and measurement of physical and chemical parameters of the surrounding environment were carried out at eight points research located in the area there Gintung City of South Tangerang, Banten Province, which is divided into four stations, each of which has two sub stations. Samples were taken and environmental chemical and physical factors were measured. The samples were then identified for each species, and identified using the Evenness Index, the Shannon-Wiener Diversity Index, and the Simpson Domination Index. The results of the research that after plunging into the field could be concluded that the gastropods found were five species, namely Pomacea caniculata, Bellamya javanica, Melanoides tuberculata, Thiara scabra, and Indoplanorbis exustus. Gastropod diversity in the area of Gintung, South Tangerang City, Banten Province, including the medium category. Evenness of the Gastropods in the area of Gintung, South Tangerang City, Banten Province was categorized as more even. There were no species that dominate the waters in this area.
\end{abstract}

Copyright $@ 2021$ LPPM Universitas Indraprasta PGRI. All Right Reserved

\section{PENDAHULUAN}

Provinsi Banten adalah salah satu provinsi yang berada di ujung barat Pulau Jawa, salah satu kota terpadat penduduknya yakni Kota Tangerang Selatan yang secara geografis masuk ke dalam wilayah administratif Provinsi Banten. Pada bagian utara berbatasan dengan Kota Tangerang, bagian selatan berbatasan dengan Kota Bogor, sebelah barat berbatasan dengan Kabupaten Tangerang, serta bagian timur berbatasan dengan Daerah Khusus Ibukota Jakarta. Kota yang berdiri pada tanggal 26 November 2008 ini berjarak $30 \mathrm{KM}$ sebelah barat Jakarta dan $90 \mathrm{KM}$ di tenggara Serang, ibukota Provinsi Banten. Secara geografis, kota yang terletak pada titik koordinat $106^{0} 38^{\prime}$ - 
$106^{0} 47^{\prime}$ BT, $06^{0} 13^{\prime} 30^{\prime \prime}-06^{0} 22^{\prime} 30^{\prime \prime} \mathrm{LS}$ ini memiliki luas $147,19 \mathrm{KM}^{2}$ (Apriyanto, 2015).

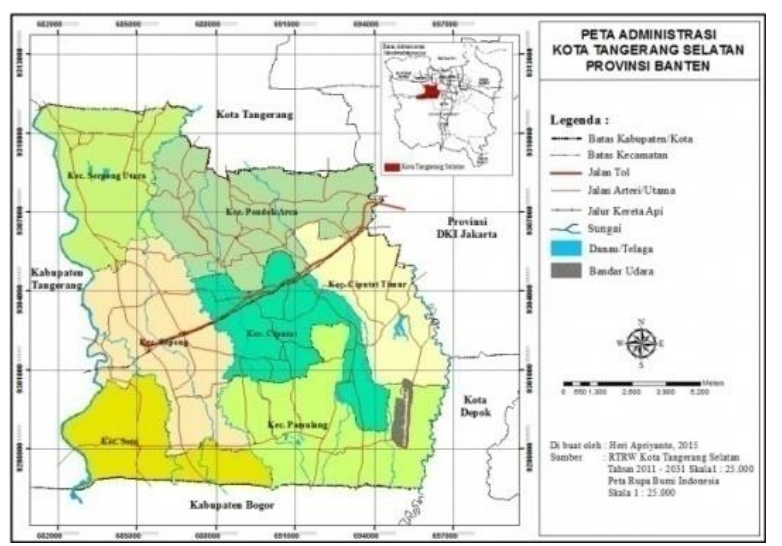

Gambar 1. Peta wilayah Tangerang Selatan (Apriyanto, 2015)

Tangerang Selatan memiliki fungsi antara lain sebagai daerah penyangga Kota Jakarta, dan masuk ke dalam konsep megapolitan Jabodetabekpunjur (Jakarta, Bogor, Depok, Tangerang, Bekasi, Puncak, dan Cianjur). Tangerang Selatan memiliki tujuh kecamatan, empat puluh sembilan kelurahan, dan lima desa (Apriyanto, 2015). Setidaknya terdapat sembilan situ yang tersebar di berbagai tempat di wilayah Kota Tangerang Selatan. Situ Rempong terdapat di Desa Rempoa, sedangkan Kelurahan Cempaka Putih terdapat tiga situ, yaitu: Situ Kayu Atap, Situ Legoso, dan Situ Bungur. Kelurahan Parigi Lama terdapat Situ Parigi, Kelurahan Pondok Benda terdapat Situ Cileduk, Kelurahan Pamulang Barat terdapat Situ Pamulang, Pondok Jagung terdapat Situ Rawa Kutuk, dan di Kelurahan Cirendeu terdapat Situ Gintung.

Situ Gintung merupakan danau buatan dengan luas 21.4 ha (Bahri dkk., 2015). Situ yang awalnya dimanfaatkan sebagai sarana irigasi pada jaman Hindia Belanda ini pernah jebol pada tahun 2009. Dahulu, areal persawahan dan ladang di sekitar Situ Gintung mendapat suplay air dari bendungan ini yang dibangun dengan tanggul setinggi 16 meter pada tahun 1932 (Harsoyo, 2010). Hindia Belanda kala itu banyak membangun tanggul dan bendungan untuk mencegah Batavia dari terjangan banjir. Situ ini adalah bagian dari daerah aliran Sungai Cisadane dan Bendungan Kali Pesanggrahan.

Menurut Kepala Balai Besar Wilayah Sungai Ciliwung Cisadane, saat pertama kali dibangun oleh Belanda, pada waktu itu Situ Gintung memiliki luas sekitar 31 ha dengan kedalaman sekitar 10 meter. Namun demikian, akibat pendangkalan luasan Situ Gintung semakin berkurang hingga pada 2010 tersisa sekitar 21.4 ha saja dengan kedalaman 4 meter (Harsoyo, 2010).

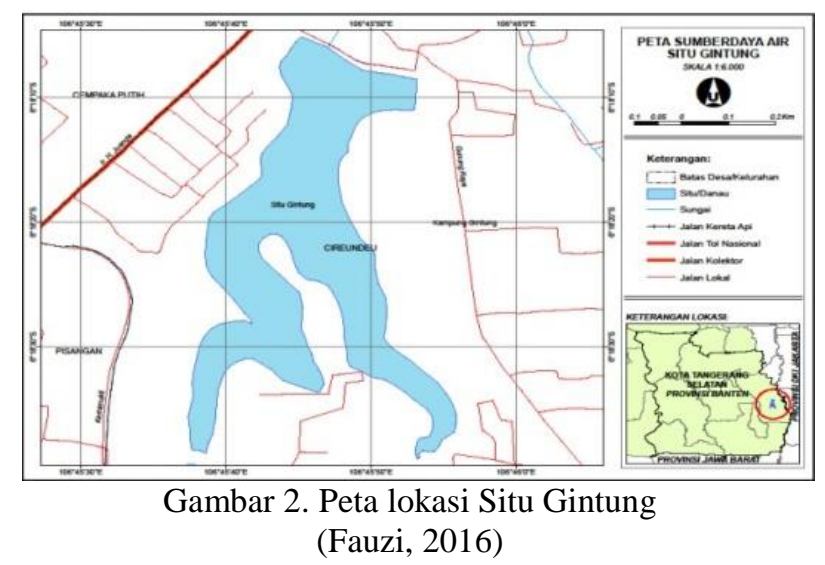

Tepat pukul 05.30 WIB pada tanggal 27 Maret 2009 , terjadi peristiwa naas dimana tanggul yang sudah berusia 76 tahun ini jebol. Penyebab utamanya bukan dikarenakan hujan deras yang mengguyur selama beberapa hari, melainkan karena usia bangunan tanggul yang sudah tua dan semakin diperparah oleh kondisi saluran pembuangan yang sudah tidak berfungsi sebagaimana pada saat awal dibangun oleh pemerintah Belanda dulu (Harsoyo, 2010).

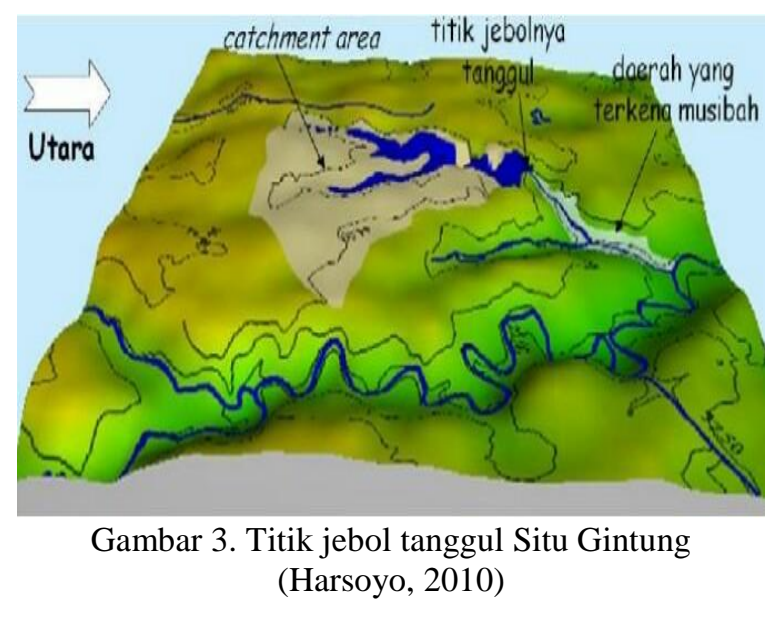

Kini, setelah dilakukan perbaikan area Situ Gintung menjadi lebih rapih dan tanggul baru pun sudah dibangun. Keberadaan cek dam dan pintu air baru yang sudah dibangun menyebabkan kondisi muka air pada musim kemarau tidak mengalami penyusutan yang tinggi (Fauzi, 2016). Senada dengan pernyataan di atas, Ahmad (48) salah satu warga yang tinggal di tepian Situ Gintung juga mengungkapkan bahwa ketika musim kemarau, debit air Situ Gintung tidak pernah kering bahkan masih terlihat melimpah dan masih dimanfaatkan warga untuk mencari ikan. 
Sepanjang tepian situ banyak dijumpai pemancing dan penangkap udang mengitari tepian perairan. Berdasarkan pengalaman visual di lokasi, peneliti menjumpai banyak ikan yang berenang di tepian Situ Gintung. Salah satu hewan lain penghuni Situ Gintung yang terlihat mencolok adalah kelompok Gastropoda, ciri dari keberadaan kelompok hewan ini antara lain adalah adanya cangkang yang sering tertinggal di tanah serta beberapa dari kelompok hewan ini menempelkan telurnya yang berwarna mencolok di tumbuhan air (Fadhilah dkk., 2013).

Gastropoda merupakan hewan yang memiliki ragam bentuk, ukuran, serta warna cangkang. Cangkang dari hewan ini digunakan sebagai pelindung untuk mempertahankan diri dari pemangsa (Arbi, 2013). Hewan ini memiliki peran penting dalam ekosistem perairan yang antara lain sebagai organisme kunci dalam rantai makanan. Selain dari pada itu, tingkat keanekaragamannya pada lingkungan juga dapat digunakan sebagai indikator pencemaran pada lingkungan perairan (Fadhilah dkk., 2013).

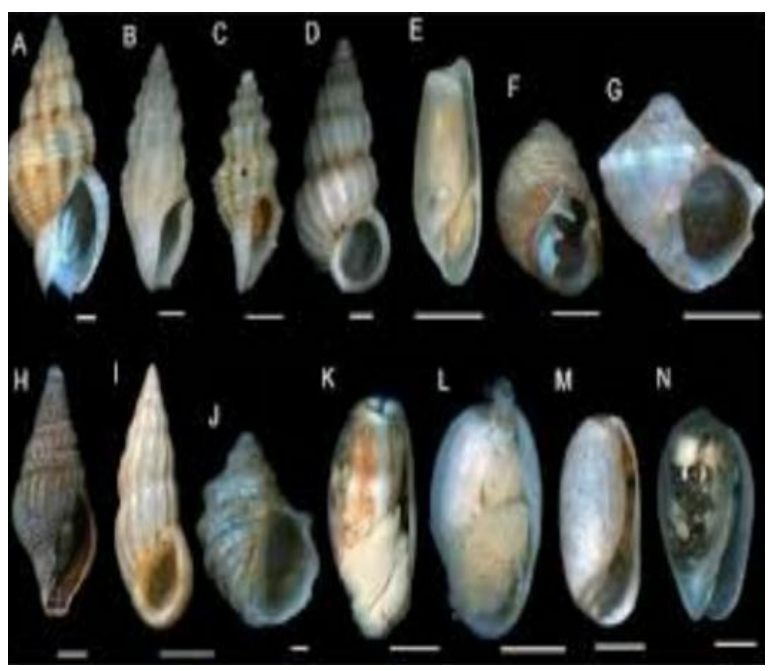

Gambar 4. Contoh cangkang Gastropoda

(Septiana, 2017)

Eksistensi Gastropoda pada suatu perairan tidak serta merta terlepas dari faktor pendukung keberadaannya, adapun faktor-faktor yang berpengaruh terhadap keberadaan Gastropoda pada suatu perairan dikelompokan menjadi dua, yakni biotik dan abiotik. Hal-hal yang menjadi faktor tersebut antara lain kedalaman, vegetasi dasaran, jenis sedimen dasaran, derajat keasaman, arus air, kekeruhan air, kadar oksigen pada perairan serta suhu lingkungan. Jika kondisi lingkungan berubah maka struktur komunitas Gastropoda pada perairan tersebut juga akan mengalami perubahan. Gastropoda memiliki peran dalam ekosistem sehingga jika struktur komunitas Gastropoda berubah, maka akan berpengaruh juga terhadap struktur komunitas organisme lainnya yang memiliki keterkaitan dengan keberadaan komunitas Gastropoda, sebagai contoh terkait rantai makanan (Vanny, 2016).

Maksud dari struktur komunitas adalah penggambaran suatu komunitas dilihat dari keragaman jenis spesies pada ruang lingkup dan juga kemelimpahan relatif pada setiap organisme terhadap keseluruhan komunitas. Kepadatan spesies Makrozoobentos dan DO memiliki hubungan yang kuat, dimana kekeruhan air yang tinggi serta rendahnya DO mengubah struktur komunitas Makrozoobentos (Vanny, 2016).

Identifikasi pada komunitas Gastropoda bertujuan untuk mempelajari bagaimana struktur komunitas yang terbentuk pada suatu habitat. Hal yang dipelajari antara lain tentang kepadatan spesies, keanekaragaman spesies, spesies penyusun, penyebaran spesies, terlebih lagi dengan kondisi Situ Gintung yang pernah jebol pada tahun 2009 yang tentunya berpengaruh terhadap perubahan komposisi komunitas habitat perairan yang sudah lama mendiami situ tersebut kemudian tergantikan dengan organisme yang baru pada komunitas yang baru. Hal ini penting untuk mengetahui kondisi ekologis perairan di Situ Gintung.

Penelitian dibatasi hanya pada identifikasi komunitas Gastropoda yang berada di Situ Gintung Kota Tangerang Selatan Provinsi Banten. Adapun struktur komunitas Gastropoda yang dimaksud meliputi keberadaan spesies, kepadatan spesies, keanekaragaman spesies, dominasi spesies, serta kemerataan penyebaran spesies Gastropoda. Berdasarkan pada latar belakang, identifikasi masalah, dan pembatasan masalah di atas, dapat dirumuskan bagaimana struktur komunitas Gastropoda yang berada di Situ Gintung Kota Tangerang Selatan Provinsi Banten serta tujuan dari penelitian ini adalah untuk mengetahui dan menganalisis struktur komunitas Gastropoda yang berada di Situ Gintung Kota Tangerang Selatan Provinsi Banten.

\section{METODE PENELITIAN}

Penelitian kualitatif digunakan oleh peneliti untuk mendapatkan hasil sebagaimana tujuan penelitian, yakni identifikasi komunitas Gastropoda di Situ Gintung Tangerang Selatan, Banten. Jenis penelitian ini dilakukan pada kondisi yang alamiah, maka peneliti hanya perlu memaparkan keadaan yang sebenarnya sesuai 
dengan yang terjadi di lapangan tanpa melalui pemberian perlakuan kepada objek yang diteliti. Kemudian hasil penelitian dituangkan dalam tulisan yang berisi suatu permasalahan yang diungkapkan dengan tata cara dan metode ilmiah (Siagian, 2016). Selain itu, pemilihan sampel dilakukan secara purposive atau teoritis bukan sampel acak atau representative. Disebabkan peneliti memiliki keinginan untuk meningkatkan cakupan data yang dicari supaya mendapatkan hasil realita yang berbagai macam di lapangan. Sehingga segala bentuk temuan akan lebih mantap karena prosesnya melibatkan kondisi serta nilai lokal yang satu sama lain saling mempengaruhi (Alwasilah, 2011).

Tabel 1. Karakteristik penelitian kualitatif

\begin{tabular}{|c|c|}
\hline Aspek & Kualitatif \\
\hline Fokus penelitian & Kualitas (hakikat, esensi) \\
\hline Akar filsafat & $\begin{array}{l}\text { Fenomenologi, interaksi } \\
\text { simbolik }\end{array}$ \\
\hline Frase terkait & $\begin{array}{l}\text { Kerja lapangan, etnografi, } \\
\text { naturalistik, grounded, } \\
\text { subjektif }\end{array}$ \\
\hline Tujuan & $\begin{array}{l}\text { Pemahaman deskripsi, } \\
\text { temuan, pemunculan hipotesis }\end{array}$ \\
\hline Desain & Kenyal, berevolusi, mencuat \\
\hline Latar & Alami, akrab \\
\hline Sampel & Kecil, tidak acak, teoritis \\
\hline Pengumpulan data & $\begin{array}{l}\text { Peneliti sebagai instrumen } \\
\text { inti, interview, observasi }\end{array}$ \\
\hline Modus analisis & Induktif (oleh peneliti) \\
\hline Temuan & $\begin{array}{l}\text { Komprehensif, holistik, } \\
\text { ekspansif }\end{array}$ \\
\hline
\end{tabular}

(Alwasilah, 2011)

Selain dari pada itu, kegiatan pengamatan atau observasi ini dilakukan untuk mengenal objek dan peristiwa melalui alat indra. Adapun pengamatan meliputi beberapa kegiatan seperti melihat, mendengar, mencicipi, meraba, mencium, dan mengukur (Kurniawati, 2007).

Data mengenai jenis Gastropoda yang terdapat di Situ Gintung juga diperoleh dari masyarakat melalui wawancara. Wawancara adalah tanya jawab dengan maksud untuk memperoleh suatu data guna keperluan. Tanya jawab ini dilakukan oleh dua pihak, yaitu orang yang mengajukan pertanyaan atau disebut dengan pewawancara dan orang yang memberikan jawaban atas pertanyaan atau disebut dengan narasumber (Siagian, 2015).

Pertanyaan merupakan alat untuk merencanakan, mengajar, berpikir, serta belajar. Pertanyaan yang baik diajukan dalam bahasa yang sederhana, jelas, langsung, dan mudah dimengerti. Pertanyaan tersebut juga harus disesuaikan dengan umur, kemampuan, dan minat responden. Adapun fungsi dari suatu pertanyaan antara lain untuk mencari tahu, memotivasi, melatih, membantu berpikir runtut, mengembangkan kemampuan berpikir, menginterpretasi, menjelaskan titik, menunjukan hubungan, menjelaskan sebab akibat, menemukan minat, membantu menghargai, mengulang pokok pikiran, menyatakan proses berpikir, mendiagnosis kesulitan, mengevaluasi, melatih, dan mengekspresikan (Kusumo, 2018).

Tabel 2. Alat Penelitian

\begin{tabular}{|c|c|}
\hline Alat & Fungsi \\
\hline $\begin{array}{l}\text { Buku kunci identifikasi } \\
\text { Molusca kelas } \\
\text { Gastropoda } \\
\text { pH meter }\end{array}$ & $\begin{array}{l}\text { Acuan identifikasi } \\
\text { Gastropoda yang } \\
\text { ditemukan } \\
\text { Untuk mengukur pH air }\end{array}$ \\
\hline Pinset & $\begin{array}{l}\text { Untuk mengambil sampel } \\
\text { Gastropoda }\end{array}$ \\
\hline Termometer & Untuk mengukur suhu air \\
\hline TDS meter & $\begin{array}{l}\text { Untuk mengukur } \\
\text { kekeruhan air }\end{array}$ \\
\hline GPS & $\begin{array}{l}\text { Untuk mengetahui lokasi } \\
\text { penelitian }\end{array}$ \\
\hline Tali Rafia & Untuk membuat transek \\
\hline Plastik sampel & Untuk memisahkan sampel \\
\hline Kertas label & Untuk menandai sampel \\
\hline Perekam suara & $\begin{array}{l}\text { Untuk merekam saat } \\
\text { wawancara }\end{array}$ \\
\hline Kamera & $\begin{array}{l}\text { Untuk pengambilan } \\
\text { gambar }\end{array}$ \\
\hline Roll Meter & $\begin{array}{l}\text { Untuk mengukur } \\
\text { kedalaman air }\end{array}$ \\
\hline Saringan $1,0 \mathrm{~mm}$ & $\begin{array}{l}\text { Untuk menyaring sampel } \\
\text { dari lumpur }\end{array}$ \\
\hline Spidol & $\begin{array}{l}\text { Untuk membuat tanda } \\
\text { pada tempat sampel }\end{array}$ \\
\hline Paralon & $\begin{array}{l}\text { Untuk mengambil sampel } \\
\text { air }\end{array}$ \\
\hline Plastik & $\begin{array}{l}\text { Untuk mengumpulkan } \\
\text { sampel kotor }\end{array}$ \\
\hline Buluh bamboo & $\begin{array}{l}\text { Untuk mengencangkan } \\
\text { transek }\end{array}$ \\
\hline Ember & $\begin{array}{l}\text { Untuk membawa sampel } \\
\text { dari situ }\end{array}$ \\
\hline Botol sampel & Untuk menyimpan sampel \\
\hline Penggaris & Untuk mengukur sampel \\
\hline Perahu & $\begin{array}{l}\text { Untuk menuju lokasi } \\
\text { pengambilan sampel }\end{array}$ \\
\hline Kayak & Untuk mendayung perahu \\
\hline Catatan penelitian & $\begin{array}{l}\text { Untuk menulis hasil } \\
\text { penelitian }\end{array}$ \\
\hline
\end{tabular}


Berdasarkan pada tujuannya, terdapat empat macam pertanyaan. Keempat jenis pertanyaan tersebut antara lain (Kurniawati, 2007):

a. Pertanyaan tentang hafalan untuk menyatakan suatu fakta.

b. Pertanyaan konvergen, dimana memiliki satu jawaban benar dan memerlukan sebuah alasan dari jawaban yang diberikan terhadap pertanyaan yang diajukan.

c. Pertanyaan divergen, dimana memiliki beberapa jawaban dan membantu untuk berpikir atau berkreasi terkait permasalahan yang ditanyakan.

d. Pertanyaan evaluasi untuk menentukan kebijaksanaan dan pembatasan dari pemberi jawaban atau responden yang sengaja dipilih berdasarkan pertimbangan kemampuan yang sesuai dengan konteks pertanyaan.

Sampel Gastropoda di Situ Gintung diperlukan sebagai data tambahan. Pengumpulan sampel dilakukan menggunakan peralatan dan bahan penelitian yang beraneka ragam guna mendukung proses pengambilan dan pencatatan sampel (Tabel 3).

Tabel 3. Bahan Penelitian

\begin{tabular}{ll}
\hline \multicolumn{1}{c}{ Bahan } & \multicolumn{1}{c}{ Fungsi } \\
\hline Alkohol & Untuk membuat awetan basah \\
\hline Aquades & Untuk membersihkan alat penelitian \\
\hline
\end{tabular}

Penelitian kualitatif lebih menitikberatkan pada social situation atau situasi yang terjadi pada keadaan sebenarnya, sehingga pada penelitian kualitatif tidak digunakan istilah populasi. Oleh karenanya peneliti dituntut untuk memahami hubungan yang terjadi antara tempat, perilaku serta aktifitas yang berlangsung selama penelitian hasil dari penelitian tidak untuk digeneralisasikan melainkan terikat pada kondisi dan situasi yang serupa dengan kondisi yang dialami saat penelitian berlangsung.

Sampel dapat diartikan sebagai sekumpulan observasi atau data hasil pengukuran yang diambil dari sebagian objek penelitian dengan menggunakan metode tertentu. Hal ini dilakukan karena ada beberapa faktor yang mendasari yakni pertimbangan waktu dan biaya, mustahil mendapatkan semua objek penelitian karena jumlahnya yang terlalu banyak, serta sifat sekumpulan sampel pada suatu wilayah yang homogen (Efendi \& Pramoedyo, 2017).

Pada penelitian kualitatif, purposive sampling digunakan sebagai teknik sampling. Hal ini dikarenakan peneliti telah menentukan sampel yang akan digunakan untuk penelitian dalam pengambilan sampelnya. Sampel penelitian yang telah dipilih memiliki tujuan sebagai pemberi informasi yang maksimum namun tidak untuk digeneralisasikan. Berikut ini adalah tahapan dalam proses pengambilan sampel, yaitu:

1. Sampel Gastropoda diambil secara random. Gastropoda yang diambil sebagai sampel pada penelitian kali ini adalah semua spesies Gastropoda yang terdapat pada plot pengamatan terdiri dari empat stasiun, yang masing-masing terbagi lagi menjadi dua titik sehingga total ada delapan titik pengambilan sampel.

2. Langkah-langkah pengambilan Gastropoda sebagai sampel adalah sebagai berikut:

a. Menentukan plot di empat stasiun sesuai arah mata angin pada tepian Situ Gintung.

b. Setiap plot diambil Gastropodanya untuk didata dan dilakukan pengukuran kondisi lingkungannya.

c. Sampel yang diperoleh disimpan dalam wadah secara terpisah dan diberi penanda.

d. Sampel Gastropoda kemudian diberi perlakuan awetan dan didokumentasi.

e. Mengidentifikasi spesies Gastropoda melalui studi pustaka dengan acuan buku identifikasi Gastropoda.

f. Menyusun tabulasi data.

Adapun metode pengambilan data yang peneliti gunakan untuk mengidentifikasi komunitas Gastropoda di Situ Gintung adalah metode triangulasi. Metode triangulasi merupakan suatu teknik dalam pengumpulan data yang menggabungkan beberapa teknik pengumpulan data serta sumber data yang ada. Adapun pada penelitian kualitatif terdapat tiga teknik yang dipakai dalam pengumpulan data, yakni metode survey digunakan oleh peneliti dalam melakukan observasi partisipasi aktif dengan cara pengamatan langsung pada empat stasiun di tepian perairan Situ Gintung yang telah ditentukan berdasarkan arah mata angin. Setiap Gastropoda yang ditemukan pada masing-masing plot kemudian diteliti dan diidentifikasi jenis spesiesnya, serta kondisi perairan secara kimia dan fisik.

Adapun ketentuan yang dilakukan dalam pengambilan Gastropoda sebagai sampel adalah dengan membuat transek berukuran $2 \times 2$ meter pada tepian Situ Gintung dan sejajar dengan 
tanggul pembatas. Kemudian dalam kuadran dibuat plot berukuran $2 \times 1$ meter sebanyak dua buah yang digunakan sebagai tempat mengambil sampel Gastropoda. Sehingga jika dijumlahkan terdapat delapan titik atau plot pengambilan sampel.

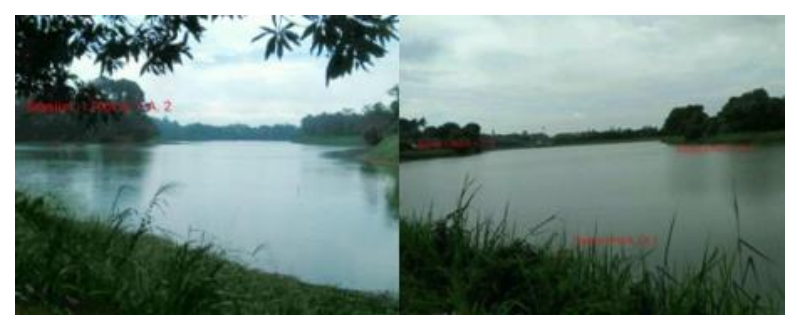

Gambar 5. Stasiun A, B, C, D

Observasi partisipasi pasif untuk melengkapi data penelitian mengenai identifikasi Gastropoda di Situ Gintung ini, perlu dicari data yang mendukung berupa literatur terkait. Adapun literatur yang peneliti gunakan adalah buku teks, karya ilmiah berupa skripsi dan jurnal, dan berbagai sumber lainnya. Literatur tersebut memiliki keterkaitan dengan masalah yang sedang dibahas dan sebagai bahan pembanding.

Sekitar tepian Situ Gintung terdapat rumah warga yang setiap harinya beraktifitas di situ tersebut. Oleh karenanya, peneliti melakukan wawancara dengan mereka guna mencari data observasi partisipasi. Wawancara dilakukan secara terstruktur, pertanyaan telah peneliti persiapkan sehingga lebih jelas arah dan tujuan wawancara dan mengacu pada jenis pertanyaan untuk mencari tahu pengalaman dan pengetahuan narasumber terkait kondisi perairan Situ Gintung dan Gastropoda yang ada di dalamnya untuk dibandingkan dengan temuan penelitian.

Dokumentasi digunakan sebagai bagian acuan dan referensi serta studi pustaka dari proses penelitian, dokumentasi juga diperlukan sebagai pembanding atas temuan dilapangan guna mencari jawaban yang lebih pasti merujuk pada teori dan pengalaman peneliti sebelumnya pada kasus yang serupa, karena tidak jarang antara penelitian yang satu dengan penelitian sebelumnya terdapat kemiripan hasil dan sering juga sedikit berbeda dikarenakan adanya berbagai faktor. Oleh karenanya, sangat penting menggunakan referensi dari penelitian sebelumnya yang serupa dan relevan dengan penelitian yang sedang dilakukan.

Indeks keragaman jenis yang digunakan adalah indeks keragaman jenis Shannon Weiner (Vanny, 2016).

$$
\begin{gathered}
H=-\sum\left(\frac{n i}{N}\right) \ln \left(\frac{n i}{N}\right) \text { atau } \\
H=-\sum P i \ln (P i) P i=\frac{n i}{N}
\end{gathered}
$$

Keterangan:

$H=$ Indeks keragaman Shannon

$P i=$ Kelimpahan relatif dari spesies ke-i

$N i=$ Indeks nilai penting jenis I atau jumlah individu suatu jenis

$N=$ Jumlah total nilai indeks penting atau jumlah total individu

Indeks kemerataan jenis dapat dihitung dengan rumus (Vanny, 2016).

Keterangan:

$$
e=\frac{H^{\prime}}{H M A X}
$$

$H^{\prime} \quad=$ Indeks keanekaragaman

$H M A X=3.3219 \times \log \mathrm{S}$

$\mathbf{S} \quad=$ Jumlah taksa

Pengukuran indeks dominasi menggunakan rumus indeks dominasi Simpson (Vanny, 2016).

$$
D=\sum_{i-1}^{s}\left(\frac{n i}{N}\right) 2
$$

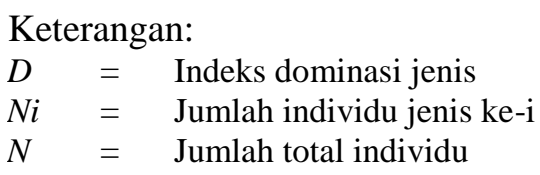

Keterangan:

$D=$ Indeks dominasi jenis

$N i=$ Jumlah individu jenis ke-i

$N=$ Jumlah total individu

\section{HASIL DAN PEMBAHASAN}

Lokasi plot pengambilan data pada empat stasiun di tepian Situ Gintung menunjukan bahwa rata-rata dalam jarak satu meter dari tepian situ sedalam $20.5 \mathrm{~cm}$ dan pada jarak dua meter dari tepian situ sedalam $45 \mathrm{~cm}$. Adapun rincian data kedalaman pada empat stasiun pengambilan data tersebut dapat dilihat pada Tabel 4.

Peneliti melakukan uji kondisi air sederhana dengan menggunakan bantuan alat TDS meter (Total Disolved Solids) atau dapat diartikan sebagai jumlah padatan terlarut. Alat ini biasa digunakan untuk mengukur jumlah partikel terlarut dalam air serta mengukur kepekatan larutan dengan satuan ppm. Hasil pengukuran menunjukan semakin ke tengah, kepekatan air semakin keruh (Tabel 5).

Kondisi air yang keruh akan berpengaruh pada berkurangnya kemampuan penetrasi cahaya matahari masuk ke dalam perairan dan sampai ke dasaran yang mana menjadi habitat hidup Gastropoda. Hal ini berbeda dengan penemuan di lapangan, dimana meskipun penetrasi cahaya juga berpengaruh kepada ketersediaan makanan bagi organisme perairan, namun semakin dalamnya lokasi pengambilan sampel semakin banyak pula individu yang ditemukan. Alasan utama dari keberadaan jumlah individu Gastropoda ini adalah karena plot satu memiliki gelombang yang lebih 
besar dibandingkan dengan plot dua pada masingmasing stasiun, selain itu berdasarkan pengamatan visual dan hasil pengambilan dasaran perairan di lapangan, dasaran plot satu lebih kasar dibandingkan plot dua pada masing-masing stasiun.

Tabel 4. Data kedalaman plot penelitian

\begin{tabular}{|c|c|c|c|c|c|}
\hline Stasiun & Titik & Kedalaman & Jarak dari Tepi & Titik A.1; B.1; C.1; D.1 & Titik A.2; B.2; C.2; D.2 \\
\hline \multirow[t]{2}{*}{$\mathbf{A}$} & A. 1 & $17 \mathrm{~cm}$ & $1 \mathrm{~m}$ & $17 \mathrm{~cm}$ & \\
\hline & A. 2 & $50 \mathrm{~cm}$ & $2 \mathrm{~m}$ & & $50 \mathrm{~cm}$ \\
\hline \multirow[t]{2}{*}{ B } & B. 1 & $15 \mathrm{~cm}$ & $1 \mathrm{~m}$ & $15 \mathrm{~cm}$ & \\
\hline & B. 2 & $40 \mathrm{~cm}$ & $2 \mathrm{~m}$ & & $40 \mathrm{~cm}$ \\
\hline \multirow[t]{2}{*}{$\mathbf{C}$} & C. 1 & $27 \mathrm{~cm}$ & $1 \mathrm{~m}$ & $27 \mathrm{~cm}$ & \\
\hline & C. 2 & $47 \mathrm{~cm}$ & $2 \mathrm{~m}$ & & $47 \mathrm{~cm}$ \\
\hline \multirow[t]{2}{*}{ D } & D.1 & $23 \mathrm{~cm}$ & $1 \mathrm{~m}$ & $23 \mathrm{~cm}$ & \\
\hline & D. 2 & $43 \mathrm{~cm}$ & $2 \mathrm{~m}$ & & $43 \mathrm{~cm}$ \\
\hline \multirow{2}{*}{\multicolumn{4}{|c|}{$\begin{array}{c}\text { Jumlah } \\
\text { Rata-rata kedalaman }\end{array}$}} & $82 \mathrm{~cm}$ & $180 \mathrm{~cm}$ \\
\hline & & & & $20.5 \mathrm{~cm}$ & $45 \mathrm{~cm}$ \\
\hline
\end{tabular}

Faktor lain yang menjadi pemicu kekeruhan pada perairan Situ Gintung adalah sampah warga yang dibuang di tempat pembuangan sampah yang tepat berada di samping ujung sungai yang mengalir ke Situ Gintung. Hal ini di benarkan oleh Ahmad (48) dimana saat hujan besar, air hujan akan menghanyutkan sebagian sampah-sampah tersebut ke perairan Situ Gintung.

Tabel 5. Kondisi padatan terlarut, $\mathrm{pH}$, dan suhu air dasaran, jenis dan jumlah spesies yang terdapat pada plot

\begin{tabular}{ccccccc}
\hline Lokasi & $\begin{array}{c}\text { Kedalaman } \\
(\mathbf{c m})\end{array}$ & $\begin{array}{c}\text { Padatan } \\
\text { Terlarut }(\mathbf{p p m})\end{array}$ & $\begin{array}{c}\mathbf{p H} \text { Air } \\
\text { Dasaran }\end{array}$ & $\begin{array}{c}\text { Suhu Air Dasaran } \\
\left(\mathbf{(}^{\mathbf{C}}\right)\end{array}$ & $\begin{array}{c}\text { Jenis } \\
\text { Spesies }\end{array}$ & Jumlah \\
\hline $\mathbf{A . 1}$ & 17 & 82 & 8.6 & 35.1 & 5 & 58 \\
\hline $\mathbf{A . 2}$ & 50 & 84 & 8.7 & 32.1 & 5 & 222 \\
\hline $\mathbf{B . 1}$ & 15 & 75 & 8.7 & 36 & 4 & 29 \\
\hline $\mathbf{B . 2}$ & 40 & 82 & 8.4 & 33.7 & 5 & 113 \\
\hline C.1 & 27 & 64 & 8.6 & 34.6 & 5 & 39 \\
\hline C.2 & 47 & 82 & 8.6 & 33.8 & 5 & 79 \\
\hline D.1 & 23 & 86 & 8.8 & 31.8 & 4 & 47 \\
\hline D.2 & 43 & 84 & 8.8 & 31.3 & 5 & 170 \\
\hline
\end{tabular}

Derajat keasaman perairan di Situ Gintung khususnya pada stasiun pengambilan data (Tabel 5), masuk dalam kategori tinggi atau kurang optimum bagi beberapa spesies Gastropoda seperti subkelas Pulmonata dan Prosobranchia yang masing-masing memiliki rentang $\mathrm{pH}$ optimum pada kisaran angka 7.0-8.4 dan 7.4-8.3. Namun demikian masih dapat dihuni oleh komunitas Gastropoda karena masih dalam rentang $\mathrm{pH}$ di atas 5 dan di bawah 9. Perairan di Situ Gintung masuk dalam kategori perairan yang cukup basa sehingga perairan tersebut tidak terlalu berbahaya bagi cangkang Gastropoda yang mengandung $\mathrm{Ca}$ dimana pada kondisi asam dapat mudah terkikis dan rapuh.
Suhu merupakan salah satu faktor penting yang mempengaruhi keberadaan komunitas Gastropoda, dimana suhu pada kisaran $20-30^{\circ} \mathrm{C}$ adalah rentang umum bagi organisme perairan tawar serta dengan suhu optimum pada kisaran $25-28^{\circ} \mathrm{C}$. Kondisi suhu perairan yang dijadikan lokasi pengambilan sampel di Situ Gintung sendiri termasuk tinggi karena berada dikisaran angka di atas $30^{\circ} \mathrm{C}$. Meskipun demikian kondisi ini sering terjadi karena pengambilan data sendiri berada pada tepian yang memiliki kedalaman kurang dari satu meter sehingga paparan sinar matahari masih sangat mudah menjangkau dasaran perairan.

Sedimen dasaran pada lokasi pengambilan sampel di Situ Gintung terbagi ke dalam beberapa jenis, yakni lumpur tanah, lumpur berbatu, dan 
lumpur berpasir. Ketiga jenis dasaran ini terdapat pada empat stasiun pengambilan data dimana pada stasiun A memiliki dasaran tanah lumpur, stasiun $\mathrm{B}$ dan $\mathrm{C}$ memiliki dasaran lumpur berbatu dan stasiun D memiliki dasaran lumpur berpasir. Kondisi dasaran yang ditemukan pada umumnya masih memiliki banyak komposisi lumpur, sehingga disukai oleh Gastropoda karena tidak melukai tubuhnya yang lunak saat bergerak dan tersapu gelombang air.

Gastropoda yang berhasil ditemukan di Situ Gintung sebanyak lima spesies yakni Pomacea canaliculata (Lamarck) dengan cangkang berwarna kuning tua sampai coklat dengan bentuk bulat. Pomacea canaliculata ditemukan pada semua titik pengamatan dan dengan ukuran lebih besar dibandingkan dengan spesies Gastropoda yang lain. Spesies yang ditemukan memiliki seluk cangkang yang membulat serta sutura yang melekuk. Umbilikus cangkang terbuka, bentuk aperture lonjong, operkulum tipis dengan inti di bagian tepi. Bellamya javanica (Von Dem Busch), spesies Gastropoda yang peneliti temukan di Situ Gintung ini memiliki ukuran rata-rata terbesar kedua setelah Pomacea canaliculata. Bentuk pilinan cangkang memuncak ke atas dengan bagian dasar berbentuk bulat. Cangkang dari spesies Gastropoda yang ditemukan ini memiliki warna coklat bercampur merah serta coklat muda. Seluk akhir cangkang berukuran besar. Sutura dangkal dan tampak jelas, ujung pilinan cangkang meruncing. Cangkang pada bagian dasar berbentuk bulat dengan umbilikus yang terbuka. Melanoides tuberculata (Muller), spesies Gastropoda yang peneliti temukan di lokasi perairan Situ Gintung ini memiliki bentuk meruncing pada bagian ujung dengan corak cangkang bertotol merah yang tersebar secara tidak merata. Ukuran terbesar yang ditemukan dari spesies ini relatif lebih kecil dibandingkan ukuran terbesar yang peneliti temukan dari spesies Pomacea canalicuata dan Bellamya javanica. Thiara Scabra (Muller), spesies Gastropoda berikutnya yang peneliti temukan di Situ Gintung ini memiliki bentuk yang hampir mirip dengan Melanoides tuberculata, hanya saja terdapat perbedaan yang lebih nyata jika lebih diperhatikan yakni tekstur cangkang yang lebih kasar dibandingkan dengan Melanoides tubercculata. Spesies ini memiliki pilinan yang berjenjang dengan ujung runcing. Operkulum berwarna coklat gelap dan berbentuk oval.
Indoplanorbis exustus (Deshayes), spesies kelima yang peneliti temukan di Situ Gintung ini memiliki bentuk cangkang yang melingkar seperti cakram dengan warna coklat muda dan cenderung kekuningan. Ukuran Indoplanorbis exustus yang ditemukan memiliki ukuran lebar 0.9 sampai 1.5 $\mathrm{cm}$. Jumlah Indoplanorbis exustus yang ditemukan tidaklah banyak, hanya beberapa individu saja dan ditemukan pada lima titik A.1; A.2; B;2; C.1 dan D.2. Berdasarkan temuan komunitas Gastropoda yang peneliti dapatkan di Situ Gintung diketahui bahwa kepadatan total kelima spesies yang ditemukan sebesar 49.2510 individu $/ \mathrm{m}^{2}$. Adapun rinciannya pada titik pengambilan A.1 kepadatan spesies sejumlah 3.6260 individu $/ \mathrm{m}^{2}$, titik A.2 lebih tinggi yakni 13.8750 individu $/ \mathrm{m}^{2}$, kemudian di titik B.1 sejumlah 2.8125 individu $/ \mathrm{m}^{2}$, selanjutnya pada titik B.2 sejumlah 7.0625 individu $/ \mathrm{m}^{2}$, titik C.1 memiliki kepadatan spesies 1.4375 individu $/ \mathrm{m}^{2}$, dan titik C.2 berjumlah 5.8750 individu $/ \mathrm{m}^{2}$. Pada titik D.1 penghitungan kepadatan spesies menunjukkan hasil 2.9375 individu $/ \mathrm{m}^{2}$, dan yang terakhir pada titik D.2 jumlah kepadatan 10.6250 individu/ $\mathrm{m}^{2}$.

Kepadatan tertinggi dari komunitas Gastropoda pada kedelapan titik yang tersebar di empat stasiun pengambilan sampel tersebut diketahui berada pada titik A.2 dengan jumlah kepadatan 13.8750 individu $/ \mathrm{m}^{2}$, yang memiliki sedimen dasaran lumpur dan derajat keasaman 8.7 dengan padatan terlarut $84 \mathrm{ppm}$ serta suhu $32.1^{\circ} \mathrm{C}$. Hal ini karena spesies Gastropoda lebih menyukai dasaran dengan tekstur lembut seperti lumpur dan kurang menyukai dasaran dengan tekstur kasar karena tidak nyaman untuk tubuh Gastropoda yang lunak. dari pada itu, suhu di titik pengambilan A.2. Selain juga berkisar $32.1^{\circ} \mathrm{C}$, angka ini lebih mendekati suhu optimum bagi Gastropoda yang berada pada kisaran $25-28^{\circ} \mathrm{C}$, sehingga sedikit lebih nyaman bagi Gastropoda jika dibandingkan dengan titik pengambilan B. 1 dengan suhu $36^{\circ} \mathrm{C}$ dan didapati kepadatan spesies Gastropoda mencapai sejumlah 2.8125 individu/ $\mathrm{m}^{2}$.

Nilai indeks keanekaragaman Shanon-Wiener mengelompokan bahwa jika nilai $H^{\prime}>3$ maka keanekaragaman jenis tergolong tinggi, jika nilai $H^{\prime} 1<H^{\prime}<3$ maka keanekaragaman jenis sedang, dan jika nilai $H^{\prime}<1$ maka keanekaragaman jenis rendah. 
Tabel 6. Jumlah individu spesies yang ditemukan

No. Spesies yang ditemukan

Jumlah Individu

Total Individu

\begin{tabular}{clccccccccc} 
& & A1 & A2 & B1 & B2 & C1 & C2 & D1 & D2 & \\
\cline { 3 - 11 } 1. & Pomacea caniculata & 12 & 20 & 3 & 5 & 8 & 6 & 4 & 4 & 62 \\
\hline 2. & Bellamya javanica & 21 & 53 & 12 & 22 & 10 & 19 & 5 & 20 & 162 \\
\hline 3. & Melanoides tuberculata & 11 & 21 & 2 & 29 & 1 & 9 & 7 & 21 & 101 \\
\hline 4. & Thiara scabra & 12 & 126 & 11 & 56 & 19 & 44 & 31 & 124 & 423 \\
\hline 5. & Indoplanorbis exustus & 2 & 2 & 0 & 1 & 1 & 0 & 0 & 1 & 7 \\
\hline & Total & $\mathbf{5 8}$ & $\mathbf{2 2 2}$ & $\mathbf{2 8}$ & $\mathbf{1 1 3}$ & $\mathbf{3 9}$ & $\mathbf{7 8}$ & $\mathbf{4 7}$ & $\mathbf{1 7 0}$ & $\mathbf{7 5 5}$ \\
\hline
\end{tabular}

Pengambilan sampel pada setiap plot menunjukan hasil penghitungan $H$, yang berbedabeda, dimana pada plot A.1 nilainya 1.4512 hal ini mengindikasikan keragaman jenis bernilai sedang pada plot ini. Kemudian di plot A.2 nilai $H$ 'nya 1.1458 sehingga masuk kategori keanekaragaman sedang. Hal serupa juga ditemukan pada plot B.1; B.2; C.1; C. 2 dan D.1 dimana masing-masing memiliki nilai keanekaragaman jenis sejumlah $1.1465 ; 1.1953 ; 1.2121 ; 1.1114 ; 1.0062$. Hal ini mengindikasikan bahwa pada ketujuh plot pengambilan sampel tersebut ditemukan keanekaragaman spesies dengan nilai sedang karena berada di angka $H^{\prime} 1<H^{\prime}<3$. Berbeda dengan ketujuh plot lainnya, keanekaragaman jenis spesies Gastropoda yang ditemukan pada plot D.2 menghasilkan angka perhitungan 0.8587. Hal tersebut mengindikasikan bahwa nilai keragaman pada plot D.2 bernilai rendah. Secara keseluruhan nilai keragaman jenis spesies Gastropoda pada semua titik plot pengambilan dengan semua jenis dan jumlah individu spesies yang ditemukan pada semua plot mengahasilkan angka $H^{\prime} 1.1731$ sehingga nilai keragaman jenis Gastropoda di perairan Situ Gintung adalah sedang.

Tabel 7. Kepadatan spesies, indeks keanekaragaman, indeks kemerataan, dan indeks dominasi

\begin{tabular}{|c|c|c|c|c|c|c|c|c|c|c|}
\hline \multirow{2}{*}{ No. } & \multirow{2}{*}{$\begin{array}{c}\text { Spesies yang } \\
\text { ditemukan }\end{array}$} & \multicolumn{8}{|c|}{ Kepadatan Spesies Tiap Stasiun (Ind/m2) } & \multirow{2}{*}{ Total } \\
\hline & & A.1 & A.2 & B.1 & B.2 & C.1 & C.2 & D.1 & D.2 & \\
\hline 1. & $\begin{array}{l}\text { Pomacea } \\
\text { caniculata }\end{array}$ & 0.7500 & 1.2500 & 1.1875 & 0.3125 & 0.5000 & 1.3750 & 0.2500 & 0.2500 & 5.8750 \\
\hline 2. & $\begin{array}{l}\text { Bellamya } \\
\text { javanica }\end{array}$ & 1.3130 & 3.3125 & 0.8125 & 1.3750 & 0.6250 & 1.1875 & 0.3125 & 1.2500 & 10.1880 \\
\hline 3. & $\begin{array}{l}\text { Melanoides } \\
\text { tuberculata }\end{array}$ & 0.6880 & 1.3125 & 0.1250 & 1.8125 & 0.0625 & 0.5625 & 0.4375 & 1.3125 & 6.3130 \\
\hline 4. & Thiara scabra & 0.7500 & 7.8750 & 0.6875 & 3.5000 & 1.1875 & 2.7500 & 1.9375 & 7.7500 & 26.4375 \\
\hline 5. & $\begin{array}{l}\text { Indoplanorbis } \\
\text { exutus }\end{array}$ & 0.1250 & 0.1250 & - & 0.0625 & 0.0625 & - & - & 0.0625 & 0.4375 \\
\hline \multicolumn{2}{|c|}{ Kepadatan Total } & 3.6260 & 13.875 & 2.8125 & 7.0625 & 2.4375 & 5.8750 & 2.9375 & 10.625 & 49.2510 \\
\hline \multicolumn{2}{|c|}{$\begin{array}{c}\text { Indeks } \\
\text { Keanekaragaman } \\
\end{array}$} & 1.4512 & 1.1458 & 1.1465 & 1.1953 & 1.2121 & 1.1114 & 1.0062 & 0.8587 & 1.1731 \\
\hline \multicolumn{2}{|c|}{ Indeks Kemerataan } & 0.9017 & 0.7119 & 0.7124 & 0.7427 & 0.7531 & 0.6918 & 0.6252 & 0.5335 & 0.7289 \\
\hline \multicolumn{2}{|c|}{ Indeks Dominasi } & 0.2477 & 0.1470 & 0.2360 & 0.1753 & 0.2293 & 0.1768 & 0.1811 & 0.1159 & 0.1227 \\
\hline
\end{tabular}

Kemerataan jenis spesies yang ditemukan tidak merata. Indeks kemerataan hasil pengambilan sampel delapan titik plot pada empat stasiun di perairan Situ Gintung berhasil menemukan dimana pada plot A.1 sejumlah 0.9017 (sangat merata), A.2 sejumlah 0.7119 (lebih merata), selanjutnya di plot
B.1 sejumlah 0.7124 (lebih merata), pada titik B.2; C.1; C.2 dan D.1 indeks kemerataan tergolong lebih merata dengan angka perhitungan masingmasing $0.7427 ; 0.7531 ; 0.6918 ; 0.6252$. Keenam titik plot pengambilan sampel menunjukan hasil yang sama dengan nilai indeks kemerataan secara 
umum dari perairan Situ Gintung, yakni 0.7289 yang bernilai lebih merata. Namun berbeda dari ketujuh plot lainnya, pada titik plot D.2 menunjukan hasil yang berbeda dimana nilai kemerataan tergolong merata atau satu tingkat dibawah kemerataan jenis spesies Gastropoda yang ditemukan pada plot lainnya yakni pada nilai perhitungan 0.5335 . Secara keseluruhan nilai dari indeks dominasi spesies pada komunitas Gastropoda di perairan Situ Gintung menunjukan hasil tidak adanya spesies yang mendominasi pada komunitas tersebut. Hasil perhitungan total menunjukan angka 0.1227 sementara pada setiap plot menghasilkan angka penghitungan sesuai dengan rumus Indeks Dominasi Simpson, yakni: A.1 (0.2477), A.2 (0.1470), B.1 (0.2360), B.2 (0.1753), C.1 (0.2293), C.2 (0.1768), D.1 (0.1811) dan D.2 (0.1159). Nilai indeks dominasi di bawah 0.5 berarti tidak ada spesies yang mendominasi dan jika nilai indeks dominasi di atas 0.5 maka ada spesies yang mendominasi komunitas tersebut.

Kemerataan jumlah individu per spesies mempengaruhi nilai indeks keanekaragaman. Jika jumlah individu pada spesies yang ditemukan pada suatu komunitas berjumlah hampir sama hal ini mengindikasikan jumlah individu per spesies merata sehingga keanekaragaman akan tinggi. Ada atau tidaknya dominasi dapat diindikasikan oleh tinggi rendahnya nilai kemerataan. Jika nilai kemerataan rendah maka terdapat dominasi suatu spesies, begitupun sebaliknya jika nilai kemerataan tinggi maka tidak ada spesies yang mendominasi pada suatu komunitas.

\section{KESIMPULAN}

Berdasarkan pada hasil identifikasi serta penghitungan sampel dari empat stasiun yang terbagi kedalam delapan plot atau titik pengambilan data di Situ Gintung, didapatkan hasil bahwa ditemukan lima spesies Gastropoda yakni Pomacea caniculata, Bellamya javanica, Melanoides tuberculata, Thiara scabra, dan Indoplanorbis exustus.

Kepadatan spesies di Situ Gintung paling tinggi adalah Thiara scabra dengan rentang kepadatan terendah sebesar 0.6875 dan rentang kepadatan tertinggi sebesar 7.8750. Sementara itu secara keseluruhan total kepadatan spesies adalah 49.2510. Penghitungan indeks dominasi mendapatkan hasil 0.1227 dimana tidak adanya spesies Gastropoda yang mendominasi wilayah perairan Situ Gintung. Selanjutnya keanekaragaman Gastropoda di perairan Situ
Gintung masuk dalam kategori sedang. Hasil penghitungan menyimpulkan indeks keanekaragaman Gastropoda di perairan tersebut yang terendah adalah 0.8587 sedangkan yang tertinggi adalah 1.4512. Kemerataan Gastropoda di Situ Gintung tergolong lebih merata dengan nilai indeks 0.7289 .

\section{DAFTAR PUSTAKA}

Ahmad. (2018). Identifikasi Filum Moluska (Gastropoda) di Perairan Palipi Soreang Kecamatan Banggae Kabupaten Majene. Skripsi. Universitas Islam Negeri Alauddin.

Alwasilah, A. C. (2011). Pokoknya Kualitatif: Dasar-dasar Merancang dan Melakukan Penelitian Kualitatif. Pustaka Jaya: Jakarta.

Apriyanto, H. (2015). Status berkelanjutan Kota Tangerang Selatan-Banten dengan menggunakan key performance indicators. Jurnal Manusia dan Lingkungan, 22(2), 260270.

Arbi, U. Y. (2013). Operkulum: bagian kunci untuk identifikasi Gastropoda yang sering terabaikan. Oseana, 38(1), 1-14.

Bahri, S. Ramadhan, F., \& Reihannisa, I. (2015). Kualitas perairan Situ Gintung, Tangerang Selatan. Biogenesis, 3(1), 16-22.

Dermawan, H. (2010). Studi Komunitas Gastropoda di Situ Agathis Kampus Universitas Indonesia, Depok. Skripsi. Universitas Indonesia.

Efendi, A. \& Pramoedyo, H. (2017). Biostatistika dengan $R$ dan MS. Excel. UB Press: Malang.

Fauzi, F. (2016). Analisis potensi wisata Situ Ciledug dan Situ Gintung di Kota Tangerang Selatan. Jurnal Pro-Life, 3(2), 83-96.

Fadhilah, N., Masrianih., \& Sutrisnawati. (2013). Keanekaragaman Gastropoda air tawar di berbagai macam habitat di Kecamatan Tanambulava Kabupaten Sigi. e-Jipbiol, 2(1), 13-19.

Harsoyo, B. (2010). Analisis faktor penyebab jebolnya tanggul Situ Gintung. JAI, 6(1), 4351.

Kurniawati, S. (2007). Ekosistem. Intan Pariwara: Klaten.

Kusumo, H. E. P. M. (2008). Penelitian Ilmiah untuk Biologi. Intan Pariwara: Klaten.

Nuha, U. (2015). Keanekaragaman Gastropoda pada Lingkungan Terendam Rob Deso Bedono Kecamatan Sayung Kabupaten Demak. Skripsi. Universitas Islam Negeri Walisongo. 
Septiana, N. I. (2017). Keanekaragaman Moluska (Bivalvia dan Gastropoda) di Pantai Pasir Putih Kabupaten Lampung Selatan. Skripsi. Universitas Islam Negeri Raden Intan.

Vanny, E. (2016). Identifikasi Komunitas Gastropoda di Situ Mahoni Universitas Indonesia. Skripsi. Universitas Indraprasta PGRI.

Wahdaniar. (2016). Keanekaragaman dan kelimpahan Gastropoda di Sungai
Je'neberang Kabupaten Gowa. Skipsi. Universitas Islam Negeri Alauddin.

Wardani, D. K. (2017). Keanekaragaman dan Kelimpahan Gastropoda di Pantai Selatan Gunung Kidul Yogyakarta. Skripsi. Universitas Islam Negeri Sunan Kalijaga. 